NBER WORKING PAPER SERIES

\title{
THE WAGES AND LANGUAGE SKILLS \\ OF U.S. IMMIGRANTS
}

Geoffrey Carliner

Working Paper 5763

\author{
NATIONAL BUREAU OF ECONOMIC RESEARCH \\ 1050 Massachusetts Avenue \\ Cambridge, MA 02138 \\ September 1996
}

This paper is part of NBER's research program in Labor Studies. Any opinions expressed are those of the author and not those of the National Bureau of Economic Research.

(C) 1996 by Geoffrey Carliner. All rights reserved. Short sections of text, not to exceed two paragraphs, may be quoted without explicit permission provided that full credit, including $\mathbb{C}$ notice, is given to the source. 


\title{
THE WAGES AND LANGUAGE SKILLS \\ OF U.S. IMMIGRANTS
}

\begin{abstract}
This paper finds that immigrants on average earned about 50 cents an hour less than nativeborn Americans in 1989. Immigrants from some regions earned considerably more than natives, while others, especially from Mexico, earned much less. This paper also finds that when immigrants first arrive in the U.S. they earn significantly less than native workers, but they close the gap by about 0.8 percentage points with each added year of residence. As a result, the wage of the typical immigrant who arrived in the 1950s and 1960s eventually surpassed the average native wage. Improvements in English language skills contributed 6 to 18 percent of this narrowing, depending on sex and education level. The remainder came from unmeasured sources of assimilation.

However, since the 1950s and 1960s the wage gap between natives and newly arrived immigrants has widened by 0.2 to 0.6 percentage points annually. Because they start with a larger disadvantage, the average wage of more recent immigrants may never exceed the average native wage. A decline in the average education of newly arrived immigrants accounts for 4 to 23 percent of the starting wage gap, and shifts in the source countries of new immigrants from Europe to Latin America and Asia account for 73 to 95 percent. Changes in English skills and in other factors have played little role in this relative decline.

This analysis also finds a significant return to English skills. Even after controlling for education, region of origin, and years of U.S. residence, workers are rewarded for speaking English well. Differences between each of the five English skill categories reported in the Census data are about the same as the return to an additional year of schooling.
\end{abstract}

Geoffrey Carliner

Institute for International Economics

11 Dupont Circle, NW

Washington, DC 20036

Carliner@iie.com 


\section{THE WAGES AND LANGUAGE SKILLS OF U.S. IMMIGRANTS \\ Geoffrey Carliner}

\section{Introduction}

Recent public discussion of the role of English in the U.S. has called attention to the language skills of immigrants. This paper examines how the wages of immigrant workers relative to U.S. natives have changed since the 1950s. I estimate how improvements in the English skills of immigrants have contributed to the catching up (assimilation) that occurs with increased residence in the U.S. I also estimate the trend in the relative wages of newly arrived immigrants (cohort effect) and the contribution of changes in country of origin, edụcation, and other immigrant characteristics to this trend.

A large literature, surveyed by Borjas (1994), uses data from two or more cross. section samples to estimate the relative earnings of native-born and immigrant workers. This literature finds that when immigrants first arrive, they earn less than native U.S. workers, but immigrants reduce this earnings gap with increased U.S. residence and often overtake native workers. However, the relative earnings of new cohorts of immigrants have been falling over time, partly because the average skills of new immigrants have declined relative to natives' skills (a moving target) and partly because the relative wages of less skilled workers, native or immigrant, have fallen since the 1970 s.

Another literature has used single cross section samples to estimate the effect of language skills on immigrants' earnings. Much of this research has focussed on Hispanic men in the U.S., but other immigrant groups and other measures of labor market performance have also received attention. McManus, Gould, and Welch (1983), Grenier (1984), Tainer (1988), Kossoudji (1988), McManus (1990), Rivera-Batiz (1990), (1991), (1992), Chiswick (1991), 
Bloom and Grenier (1992), Chiswick and Miller (1992), Daneshavry et al (1992), and Chiswick (1993) all report that immigrants receive substantial returns for their English language skills, both before and after holding other characteristics constant. Although point estimates vary by sample, measures of language skills, and other aspects of specification, all these studies find significant returns to English skills.

Other studies report similar results for other receiving countries. Carliner (1981), Chiswick and Miller (1988), Bloom and Grenier (1992), and Chiswick and Miller (1992) find that immigrants to Canada earn a significant wage premium for speaking English or French. Chapman and Iredale (1993) and Chiswick and Miller (1995) for Australia and Dustmann (1994) for Germany find that immigrants receive substantial returns to speaking or writing the dominant language of those countries.

None of these studies examines changes in immigrants' language skills in a way that distinguishes between changes in the skills of newly arrived immigrants (cohort changes) and changes that occur with increased residence in the host country (assimilation). They also do not estimate the contribution of these two types of changes in language skills to earnings differences between immigrants and natives. This paper extends the research on cohort and assimilation effects pioneered by Borjas (1985) to include the contribution of language skills, using pooled data from the 1980 and 1990 U.S. Censuses of Population.

The next section presents a framework for analyzing assimilation and cohort effects on the relative wages of immigrants. The third section describes the data used in the estimation and presents descriptive information on the wages, English skills, and education of immigrants by region of origin. The fourth section discusses the results of wage regressions, while the 
fifth section calculates the contribution of different characteristics to assimilation and cohort effects. A conclusion summarizes the paper's findings.

\section{Measuring Assimilation}

Immigrants typically arrive in the U.S. with less human capital than natives, and when they first enter the U.S. labor market they receive lower wages. On average, immigrants have slightly less schooling than native workers. They also know less about American customs and work practices when they arrive. Their English skills are generally weaker, and they do not have as wide a network of friends and relatives to learn of job openings.

With increased residence in the U.S., immigrants usually improve these informal types of human capital. They acquire greater knowledge of U.S. labor market practices, and often invest time and effort in leaming better English. As a result, additional experience has a greater effect on immigrants' wages than on natives' wages, and the gap between them narrows. Whether immigrants eventually overtake natives is a question of some dispute. In any case, the faster growth in wages for immigrants than for natives is a measure of assimilation.

Over calendar time, other factors also affect the relative wages of immigrants and natives. The human capital of newly arrived immigrants may change, including average education, English language skills, the distribution of source countries, and other characteristics. Changes in U.S. immigration law, especially in the 1960s, and political and economic changes in many countries around the world have resulted in large shifts in the home countries of immigrants over the past 30 years. Shifts in labor demand may also raise 
or lower average wages for all workers over time. Improvements in technology, and increases in physical and human capital have historically raised wages over long periods, though perhaps not in the recent past.

Equation (1) captures this story.

$$
\text { (1) } w_{i t}=a_{0}+a_{1} I_{1}+a_{2} Y S M_{1 t}+a_{3} Y R M_{1}+a_{1} E x p_{1 t}+a_{5} T+e_{1 t}
$$

In this simple model, $w_{i n}$ is the $\log$ of the hourly wage of the ith individual in year $t$. I is a dummy variable equal to 1 for immigrants and zero for natives, and $\alpha_{1}$ is the wage differential between natives and new immigrants. YSM is the number of years since entry for an immigrant in year $t$ and zero for natives. YRM is the year of arrival for immigrants and zero for natives. Exp is the standard measure of experience, equal to an individual's age in year $\mathrm{t}$ minus years of education minus 6 . T reflects labor market conditions in year $\mathrm{t}$, as well as changes over time in the average education and other skills of native workers. In this model, $\alpha_{2}$ is the rate of assimilation, and $\alpha_{3}$ captures the simple trend in the human capital of newly arrived immigrants. The number of years required for immigrants who arrived in year m to catch up with natives is $\left(-\alpha_{1}-\alpha_{3} m\right) / \alpha_{2}$

Not all researchers have used this model to estimate assimilation and cohort effects. Early studies, for example Chiswick (1978) and Carliner (1980), relied on cross section data. in which YRM and YSM were not separately identified, since YSM $\equiv \mathrm{T}-\mathrm{YRM}$ and T is the same for all observations. Because of data availability, most studies of the wage effects of language skills have also used one cross section. These studies implicitly assumed that cohort effects are zero, which may have been reasonable for immigrant flows from World War II 
until 1970 but does not seem to be true for flows since then. Fortunately, it is now possible to pool cross sectional data sets. This allows identification of both assimilation and cohort effects.

Equation (1) is designed to measure how much entering immigrants earn relative to natives, not how much they earn relative to natives with similar characteristics. Therefore it does not include measures of their human capital, including their education and country of origin. If the average schooling of new immigrants fell sharply over calendar time, their wages relative to natives' would fall, and the number of years of residence required for catching up with natives would rise. But the estimate of $\alpha_{3}$ in an equation which included education or other personal characteristics would not reflect changes in the human capital of new immigrants, and therefore such variables are not included in equation (1). A measure of experience must be included in the equation, however, since the cohort of immigrants who arrived in year $t$ is aging but the stock of natives is not. Failing to control for experience would attribute all the wage growth of immigrants to assimilation and none to the normal process of wage growth over the life cycle.

Equation (1) will answer the question of how fast assimilation occurs and whether immigrant quality is changing over time, but additional equations are needed to estimate the contribution of increasing English language skills and other characteristics to this process. Equation (2) is a standard wage equation that includes English skills (Lang) and other personal characteristics such as education $(X)$ as well as the independent variables in equation (1). 
(2) $w_{i t}=\beta_{0}+\beta_{1} I_{1}+\beta_{2} Y S M_{i t}+\beta_{3} Y R M_{1}+\beta_{1} \operatorname{Exp}_{1 t}+$

$\beta_{5} \operatorname{Lang}_{i t}+\beta_{6} X_{1}+\beta_{7} T+u_{1 t}$

The full assimilation effect is then the total derivative of $w$ with respect to YSM.

(3) $\frac{d w}{d Y S M}=\frac{\partial w_{i t}}{\partial Y S M}+\left(\frac{\partial w}{\partial L a n g}\right)\left(\frac{\partial L a n g}{\partial Y S M}\right)+\left(\frac{\partial w}{\partial X}\right)\left(\frac{\partial X}{\partial Y S M}\right)$

$$
=\beta_{2}+\beta_{5}\left(\frac{\partial L a n g}{\partial Y S M}\right)+\beta_{6}\left(\frac{\partial X}{\partial Y S M}\right)
$$

Similarly for the full cohort effect,

(4) $\frac{d w}{d Y R M}=\beta_{3}+\beta_{5}\left(\frac{\partial L a n g}{\partial Y R M}\right)+\beta_{6}\left(\frac{\partial X}{\partial Y R M}\right)$

The remaining partial derivatives in equations (3) and (4) can be estimated in regressions of language skills and other characteristics on YSM and YRM, similar to equation (1) but including only immigrants.

(5) $\operatorname{Lang}_{i t}=\lambda_{0}+\lambda_{1} Y_{S M_{1 t}}+\lambda_{2} Y_{R M_{i}}+\lambda_{3}$ Agem $_{1}+V_{1 t}$

(6) $X_{i t}=\gamma_{0}+\gamma_{1} Y S M_{i t}+\gamma_{2} Y R M_{1}+e_{i t}$ 
Equation (2) estimates cohort $\left(\boldsymbol{\beta}_{3}\right)$ and assimilation $\left(\boldsymbol{\beta}_{2}\right)$ effects on wages, holding constant individuals' English language skills and other observed human capital (X). These partial wage effects would not reflect either a dramatic decline in the ability of new immigrants to speak English or large improvements in English skills with residence. Equations (5) and (6) estimate cohort $\left(\lambda_{2}\right)$ and assimilation $\left(\lambda_{1}\right)$ effects on language ability and on other characteristics $\left(\gamma_{2}\right.$ and $\left.\gamma_{1}\right)$.

Equation (5) includes a measure of the age at arrival (Agem) because immigrants who arrived in the U.S. many years ago and are still in the sample arrived at younger ages on average than more recent immigrants in the sample.' Since age at arrival has a large effect on English language skills, it must be included in equation (5) so that cohort and assimilation effects will not be misestimated because the sample is censored by current age.

The full assimilation effect on wages is therefore $\beta_{2}+\beta_{3} \lambda_{1}+\beta_{6} \gamma_{1}$ and the share of wage assimilation due to the improvement in language skills that comes with increased residence in the U.S. is simply $\beta_{5} \lambda_{1} /\left(\beta_{2}+\beta_{3} \lambda_{1}+\beta_{6} \gamma_{1}\right)$. Similarly, the cohort effect on wages can be separated into the portion that comes from changing English skills of new immigrants $\left(\beta_{5} \lambda_{2}\right)$, the portion that comes from changes in other measurable characteristics is $\left(\beta_{6} \gamma_{2}\right)$ and the portion that comes from improvements over calendar time in the unobserved labor market skills of new immigrants $\left(\beta_{3}\right)$.

1 Age at arrival (Agem) plus years since arrival (YSM) equals current age. People over 64 are excluded from the sample. Therefore Agem+YSM/65. If YSM is large, Agem must be small. Because of retirement, death, and return migration, even if there were no age restriction on the sample it would be censored by current age. 


\section{Data}

The data used to estimate these equations come from the 1980 and 1990 Census of Population. Individuals were included in the regressions if they were between 18 and 64 years old, worked at least $\mathbf{4 0}$ weeks during the year preceding the Census, and usually worked positive hours each week. The wage rate was calculated as income earned during the preceding year, in 1989 dollars, divided by weeks worked last year times usual hours worked per week. Individuals whose wage in 1989 dollars was less than $\$ 1.50$ per hour were excluded from the sample.

Census data include the interval in which immigrants entered the U.S. but not the exact year. The midpoints of these intervals were used to define a continuous measure of YRM, set equal to zero for the earliest immigrants in the sample. YSM was defined as the Census year of the observation minus the midpoint of the interval, and Agem was defined as age in the Census year minus YSM. Immigrants who arrived before 1950 were dropped from the sample, since YRM, YSM, and Agem could not be measured with any precision for this open ended category.

The 1980 and 1990 Censuses (but not earlier Censuses) asked respondents if they spoke English only, very well, well, not well, or not at all. I used this information to create a continuous measure of English skills similar to a grade point average, with $\mathbf{4}$ for speaking only English and 0 for speaking no English. I also defined dummy variables for seven region of origin categories: English speaking countries, Mexico, other western hemisphere, Europe, Africa and the Middle East, South Asia, and East Asia. All countries from which at least half the immigrants in the 1990 Census reported speaking only English were classified as English 
speaking. This category included Canada, Bermuda, Jamaica, Anguilla, Antigua, Aruba, Bahamas, Barbados, Cayman Islands, Grenada, Montserrat, St. Barts, St. Kitts, St. Lucia, St. Vincent, Trinidad, Turks and Caicos, Belize, Guyana, United Kingdom, Ireland, Gibraltar, Liberia, Zimbabwe, South Africa, Australia, and New Zealand. Countries of the former Soviet Union were included with continental European countries. The Middle East was defined to extend from Turkey to Iran. South Asia includes all countries from Afghanistan to Bangladesh. East Asia includes China, Burma (Myanmar) and countries eastward into the Pacific Ocean. A classification based on country of origin is necessary in the absence of information on mother tongue in the Census data. Unfortunately, it results in the anomaly that a small number of immigrants from English speaking countries (Canada) do not speak English and other immigrants from nonEnglish speaking countries (India) were raised speaking only English.

Much recent discussion in the popular press suggests that immigrants suffer a large wage disadvantage in the U.S. In fact, the wage difference for fulltime male workers in 1989 was only 54 cents. As Table 1 shows, many immigrant groups earn more money and are better educated than natives. Only immigrants from Latin America and East Asia have lower average wages than natives, and only Latin American and European immigrants have less education. Indeed, South Asians, the highest performing immigrant group, have on average 2.2 years more schooling and eam $\$ 4.75$ more per hour than native workers. Furthermore, most working immigrants have strong English skills. Less than 10 percent of Europeans, Africans and Middle Easterners, and South Asians speak English not well or not at all. Only among Latin Americans, especially Mexicans, is there a substantial percentage who do not 
speak English well.

\section{Cohort and Assimilation Effects}

To estimate cohort and assimilation effects on the wage gap between immigrants and natives, I estimated a version of equation (1). The dependent variable was the log of the hourly wage. The independent variables included YRM, YSM and YSM squared, Experience and Experience squared, and dummy variables for immigrants and for observations from the 1990 census.

Equation (1) implicitly assumes that shifts in labor demand over time affect immigrants and natives similarly. For the decade of the 1980s, this is probably not true. Katz and Murphy (1992), Levy and Murnane (1992), and others have documented the shift in labor demand in favor of highly skilled workers. Since immigrants are less skilled than natives, their wages have suffered more during the 1980 s from the shift in labor demand. Constraining period effects to be the same for immigrants and natives will therefore yield underestimates of assimilation. An alternative is to allow $\alpha_{s}$, the coefficient on the year of the observation, to vary by education category. To the extent that immigrants and natives with the same education compete in the same labor markets, this approach will control for the increased wage inequality between 1980 and 1990 . If immigrants are less skilled than natives with the same education, this approach will still underestimate assimilation, though by less than constraining period effects to be equal for all workers.

The disadvantage of estimating period effects separately by skill level is that it controls for changes over time in the distribution of immigrants among education categories. 
Thus any change in the percentage of immigrants who were, for example, high school graduates, would not be measured as a change in quality, though changes in average education within each category would still be reflected in estimates of $\alpha_{3}$.

Table 2 presents estimates of coefficients and standard errors from log wage regressions for all men and all women, and separately for workers with and without schooling beyond high school. For both sexes and education groups, the results indicate that natives eam significantly higher wages than new immigrants. Natives' advantage is considerably larger over less educated immigrants of both sexes than over immigrants with postsecondary schooling. For men, the gap between natives aid new immigrants is about 11 percent for workers with more than high school and 15 percent for high school or less. For women the differences are 10 percent and 18 percent for the two education groups.

The results also indicate a trend increase in the wage gap between natives and new immigrants of about 0.2 percentage points per calendar year for women and for men with postsecondary schooling and an annual decline of 0.6 percentage points for men with high school or less. During the 25 years between the change in immigration laws in the 1960 s and the 1990 Census, the wage gap for such men widened by 15 percentage points. On the other hand, immigrants' wages grow more rapidly with experience than the wages of natives. Each additional year of residence in the U.S. increases immigrants' wages relative to natives' by about 0.8 percentage points. This rate of catching up is slightly larger for women than for men and more concave for the well educated, but surprisingly similar across sex and 
education categories. $^{2}$

Table 2 also presents coefficients from regressions including all men and all women. These estimates assume, implausibly, that shifts in labor demand during the 1980 s affected the wages of immigrants and natives similarly. Compared with the regressions by education category, they show a smaller wage decline during the decade for men, and a wage increase instead of a wage decrease for women. Because it underestimates the effect of the shift in labor demand on immigrants' wages, this specification also yields higher estimates of the downtrend in wages for new immigrants and smaller estimates of the rate of catching up.

The worsening position of immigrants on arrival makes it harder for them to catch up with natives. Table 3 presents estimates, derived from the coefficients in Table 2, of the number of years required for average immigrants arriving in 1955, 1965, 1975, and 1985 to overtake natives, by sex and education category. Male immigrants with postsecondary schooling who arrived in the U.S. in 1955 could expect to earn as much as natives within 12 years, while similar immigrants who arrived in 1985 would require 21 years for overtaking. According to these estimates, the typical male immigrant without postsecondary schooling who arrived in 1955 overtook the typical native worker after 19 years. However, by 1985 the number of years to overtaking was 46 , about as long as a high school graduate works in a lifetime. Immigrant women required fewer years to overtake native women, but the pattern was similar. Those with postsecondary schooling who arrived in 1955 caught up with similar

2 I also ran regressions which included separate variables for YSM and YSMSQ for immigrants who arrived in the 1970s and the 1980s. The coefficients on these interaction terms were generally insignificant for men and small and negative for women. They suggest that recent immigrants have had about the same assimilation or catch-up rates as earlier immigrants. 
natives in only 6.5 years, but those who arrived in 1985 required 12.5 years to catch up. The typical immigrant woman without postsecondary schooling who arrived in the U.S. in 1955 caught up after 16.4 years, but similar women who arrived in 1985 will catch up only after 41.5 years of residence.

To examine the contribution of changes in English skills, education, and region of origin to the wage gap between immigrants and natives, I then estimated a log wage regression which included dummy variables for the language and region of origin categories, education, education squared, as well as YRM, YSM, YSM squared, Experience (age minus education minus 6), Experience squared, and a dummy variable for observations from the 1990 Census.

The results, presented in Table 4, indicate that the trend decline in the relative wages of newly arrived immigrants is completely explained by changes over time in English skills, region of origin, and education. Once these characteristics are held constant, the coefficient on year of arrival becomes very small and insignificant for all four sex-education categories. (Note that the coefficients and standard errors for YRM in Table 4 have been multiplied by 100 so they could be displayed with the same number of places as the other coefficients.) However, rates of assimilation are little changed from the coefficients in Table 2. Immigrants narrow the wage gap with natives by about 0.8 percentage points per year, even after adjusting for other factors.

Workers with weak English skills suffer large wage penalties, especially men and especially workers with postsecondary education. Even after controlling for education, region of origin, and years of U.S. residence, well educated men who speak only English eam 5.4 
percent more than similar men who speak English very well, 15 percent more than men who speak English well, 22 percent more than men who speak English poorly, and 39 percent more than men who speak no English. For less educated men the differentials range from 3.4 percent to 23 percent. The differentials for women are about half to two-thirds the differentials for men. ${ }^{3}$

These rates of return from moving up a language category are roughly equal to the rates of return from an additional year of education. The wage advantage between workers with 16 years of schooling over those with 15 years is 11 percent, and the increase from 11 to 12 years is 8 percent. Learning to speak better English presumably requires an investment of time, energy, and perhaps money. Therefore it should not be surprising that many immigrants do not speak fluent English, even though the rewards for doing so are large. Not everyone graduates from high school, even though there are large returns to additional years of formal education.

Although many immigrant groups earn higher wages than natives, once differences in education and other factors are taken into account, most new immigrants earn significantly less than natives. However, the adjusted wage disadvantage of new immigrants relative to natives, as measured by the coefficients on the region of origin dummies, varies widely by

${ }^{3}$ Rivera-Batiz (1992) estimates wage regressions using both self-assessed English skills and skills as measured by a test, and finds larger wage differentials by skill level for the test scores. Thus the wage differentials reported here are probably too low. It is curious that men who report speaking English very well earn less than similar men who report speaking only English. Evidentally speaking another language occasionally is associated with lower English skills than speaking English exclusively. In a regression restricted to native-born men, those who spoke only English earned significantly more than those who spoke English very well. 
region of origin. Moreover, it is generally larger for immigrants with post-secondary schooling than for those without. For instance, well educated newly arrived European men earn 15 percent less than similar natives, while less educated European men eam 10 percent less than similar natives. For women, the differences are 17 percent and 0.5 percent. Similarly, the wage disadvantage for well educated Mexicans is 26 percent for men and 25 percent for women, but only 5 and 9 percent for less educated men and women. Among new immigrants from English speaking countries and from Africa and the Middle East, the less educated actually earn more than similar natives, while the well educated earn significantly less.

Borjas (1994) and Jasso and Rosenzweig (1986) have suggested that immigrants from developed countries can transfer their skills more easily than immigrants from developing countries. The pattern of regional coefficients provides very weak support for this hypothesis. Among less educated men, immigrants from Europe and from English speaking countries do relatively well, but so do immigrants from Africa and the Middle East. Among well educated men, immigrants from English speaking countries, South Asia, and Europe earn more than other immigrant groups, adjusted for other characteristics. Among women, the coefficients for immigrants from developing countries are often larger than the coefficients for developed countries, though the differences are generally not statistically significant.

\section{Changes in English Skills, Region of Origin, and Education}

English skills, region of origin, and education are all important in explaining wage differences among immigrants, but how important are they in explaining changes in the 
"quality" of new immigrants since the 1960s? How much have changes in these characteristics among newly arrived immigrants lowered their wages relative to natives? How much have improvements in language skills and education with increased time spent in the U.S. contributed to narrowing the wage gap?

Answering these questions requires estimating equations (5) and (6), which explain how individual characteristics change with year of migration (YRM) and with years since migration (YSM). As explained above, I used a measure of English skills similar to a grade point average to estimate cohort and assimilation effects on language ability. The independent variables included YRM, YSM, YSM squared, Age at migration (AGEM), and AGEM squared. Coefficients and standard errors are shown in Table 5. The results indicate a significant trend decline in language skills for new immigrants over time and significant improvements in skills with increased U.S. residence.

The distribution of newly arrived immigrants by region of origin has shifted dramatically during the past 40 years. Table 6 presents the percentage distribution by decade of arrival, calculated for the 1990 sample of working immigrants used to estimate the wage regressions. ${ }^{5}$ As has been well documented elsewhere, the percentage of immigrants from Europe fell from 47.4 percent during the 1950 s to 8.4 percent during the 1980 s. The percentage from English speaking countries fell from 19.7 percent to 10.5 percent. In

4 These estimates come from Carliner (1995), which has a more complete discussion of English language skills among U.S. immigrants.

5 Calculating region of origin by decade of arrival from 1990 Census data implicitly assumes that rates of attrition due to return migration or mortality are the same by region of origin. For further discussion of the difficulties of estimating rates of return migration, see Borjas and Bratberg (1994). 
contrast, the percentage of immigrants from Mexico and from other western hemisphere countries rose from 10.4 and 8.4 percent to 23.4 and 22.7 percent respectively from the 1950 s to the 1980s.

This shift in region of origin has been accompanied by a small decline in the average education of new immigrants. As Table 6 shows, in 1990 immigrants who entered the U.S. in the 1950s reported having 12.9 years of education on average, compared with 11.5 years for immigrants who arrived during the 1980s. This decline in the average education of immigrants over time contrasts sharply with the average education of natives, which has increased considerably since the 1950 s. $^{6}$

Immigrants' place of birth does not change with increased U.S. residence, but education may. Many immigrants come to the U.S. with their parents and attend school as a matter of course. Others come in order to attend universities, and then decide to remain in the U.S. permanently. Assuming that immigrants acquire all their education before arrival, and therefore that it is not part of the assimilation process, is clearly not accurate. On the other hand, it is also not valid to attribute all the schooling received by an immigrant who arrived as an infant to assimilation, since such people would presumably have received some schooling even if their parents had not chosen to immigrate.

A full treatment of differences between immigrants who arrive in the U.S. as adults,

- Borjas (1994), Table 4 reports that in 1990 the percentage of high school dropouts among civilian male employees aged 25-64 rose from 26 percent for immigrants arriving during the 1950s to about 38 percent for immigrants arriving during the $1980 \mathrm{~s}$. $\mathrm{He}$ also reports that the percentage of high school dropouts among 1950s immigrants fell from 47 percent to 26 percent from the 1970 Census to the 1990 Census. Increasing exaggeration of educational achievement with age, and greater return migration, retirement or mortality among high school dropouts may all contribute to this pattern. 
those who arrive as children, natives who are the children of immigrants, and native children of natives is beyond the scope of this paper. However, it is interesting to note that among immigrant groups with less education than natives, individuals who arrived as children receive more schooling than those who arrived as adults. As shown in Table 7, Mexicans who immigrated when they were 10 years old or less had 11.3 years of schooling, versus 6.7 years for those who arrived when they were 26 or older. By contrast, among immigrant groups with more education than natives, the reverse is true. South Asians who were 10 or younger on arrival had an average of 14.8 years of education versus 15.5 years for South Asians who were 26 or older when they arrived. Assimilation seems to involve a regression towards the native mean. It is also interesting to note that the return to a year of foreign schooling is worth about 7 percent less than a year of U.S. schooling, a small but statistically significant difference.

In calculating the contribution of changes in individual characteristics to cohort and assimilation effects on relative wages, I abstracted from these issues and assumed that immigrants do not increase their years of schooling after they arrive in the U.S., ie, that $\gamma_{1}=$ 0 in equation (6). I then regressed years of schooling on year of arrival (YRM). The estimated trend in immigrant education is a decline of 0.046 per year (standard error = 0.0015). In other words, over a 30 year period the average education of new immigrants has declined by 1.4 years.

7 Foreign education was calculated as the lower of age at migration minus 6 or total years of education. This variable was included in a wage regression along with total years of education, education squared, and the other variables shown in Table 4. As noted above, Census data only reports intervals for the date of arrival. Therefore the measures of years of U.S. residence, age at migration, and foreign education all include large errors. 
To calculate the estimated contribution of changes in English skills, education, and region of origin to cohort and assimilation effects, I followed the procedure described above at the end of section II. The change in English skills was calculated from the coefficients on YRM or YSM and YSM squared in Table 5. The change in education comes from the regression described in the preceding paragraph. 'The change in region of origin was the percentage distribution for 1980 s immigrants minus the percentage distribution for 1950s immigrants. These changes were then multiplied by the appropriate coefficients in the wage regressions in Table 4 to produce the contribution of each variable. These contributions were then divided by the total cohort and assimilation effects, calculated according to section II.

Table 8 reports these shares by sex and education category. These calculations indicate that improvements in English language skills contribute about 16 to 18 percent to the narrowing of the wage gap between male immigrants and natives that occurs with increased U.S. residence, and about 6 to 10 percent for female immigrants. Most of the assimilation seems to be the result of increases in other forms of human capital by immigrants, for instance better knowledge of U.S. work practices or greater ability to find well paid jobs. The results also indicate that changes in the English skills of new immigrants have had little effect in their declining relative wages over time. The trend decline in their education has been substantially more important, but by far the most important source of the relative wage decline has been the shift in source countries away from Europe towards Latin America and Asia. For women, I estimate that this shift has been responsible for 73 to 89 percent of the trend decline, and for men from 87 to 95 percent. These findings are roughly consistent with estimates in Borjas (1992). 


\section{Conclusions}

The average immigrant earns about 50 cents less than the average native worker, but many immigrant groups in the U.S. eam higher wages than native workers and many have higher average education. Furthermore, the majority of immigrant workers speak English well or very well. Only among Latin American immigrants do a substantial minority report speaking English not well or not at all.

When they first arrive in the U.S., immigrants earn significantly less than natives. With each year of added residence in the U.S. this wage gap narrows by about 0.8 percent. As a result, the wage of the typical immigrant who arrived in the 1950s and 1960s eventually surpassed the average native wage. This overtaking occurred more quickly for women and for well educated immigrants, but it also occurred for less educated men. Improvements in English language skills contributed 6 to 18 percent of this narrowing, depending on sex and education level. The remainder came from unmeasured sources of assimilation.

However, since the 1950s and 1960s the wage gap between natives and newly arrived immigrants has widened by 0.2 percent to 0.6 percent annually. Because they start with a larger disadvantage, on average more recent immigrants may never earn more than natives. A decline in the average education of newly arrived immigrants accounts for 4 to 23 percent of the starting wage gap, and shifts in the source countries of new immigrants from Europe to Latin America and Asia account for 73 to 95 percent. Changes in English skills and in other factors have played little role in this relative decline.

This analysis also finds a significant return to English skills. Even after controlling for education, region of origin, and years of U.S. residence, workers are rewarded for 
speaking English well. Differences between each of the five skill categories reported in the Census data are about the same as the return to an additional year of schooling. The rewards are larger for men than for women and for well educated workers than for others, but they are positive and significant for all sex-education categories. 


\section{References}

Bloom, David, and Gilles Grenier, "Earnings of the French Minority in Canada and the Spanish Minority in the United States," In Immigration, Language and Ethnic Issues:

Canada and the United States, ed. Barry Chiswick, Washington, D.C.: American Enterprise Institute, 1992.

Bloom, David, and Gilles Grenier, "Language, Employment, and Earnings in the United States: Spanish-English Differentials from 1970 to 1990," Working Paper No. 4584, National Bureau of Economic Research, December 1993.

Borjas, George, "Assimilation, Changes in Cohort Quality, and the Earnings of Immigrants," Joumal of Labor Economics 3:4, October 1985.

----., "National Origin and the Skills of Immigrants in the Postwar Period," in immigration and the Work Force, ed. George Borjas and Richard Freeman, Chicago: University of Chicago Press, 1992.

------, "The Economics of Immigration," Joumal of Economic Literature 32:4, December 1994.

Borjas, George, and Bernt Bratsberg, "Who Leaves? The Outmigration of the Foreign Born," Working Paper No. 4913, National Bureau of Economic Research, November 1994.

Carliner, Geoffrey, "Wages, Eamings, and Hours of First, Second, and Third Generation American Males," Economic Inquiry 18:1, January 1980.

-------, "Wage Differences by Language Group and the Market for Language Skills in Canada," Journal of Human Resources 16:3, Summer 1981.

------, "The Language Ability of U.S. Immigrants: Assimilation and Cohort Effects," NBER Working Paper No. 5222, August 1995.

Chapman, Bruce and Robyn Iredale, "Immigration Qualifications: Recognition and Relative Wage Outcomes, Intemational Migration Review 27:2, Summer 1993.

Chiswick, Barry, "The Effect of Americanization on the Earnings of Foreign-Born Men," Journal of Political Economy 86:5, October 1978.

--, "Speaking, Reading, and Earnings among Low-skilled Immigrants, ". Journal of Labor Economics 9:2, April 1991.

-----, "Soviet Jews in the United States: An Analysis of their Linguistic and Economic 
Achievement," International Migration Review 27:2, Summer 1993.

Chiswick, Barry and Paul Miller, "Earnings in Canada: The Roles of Immigrant Generation, French Ethnicity, and Language." In Research in Population Economics 6, 1988.

- - "Language in the Labor Market: The Immigrant Experience in Canada and the United States." In Immigration, Language and Ethric Issues: Canada and the United States, ed. Barry Chiswick, Washington, D.C.: American Enterprise Institute, 1992.

-., "The Endogeneity between Language and Earnings: International Analysis," Journal of Labor Economics 13:2, April 1995.

Daneshavry, Nasser, Henry Herzog, Richard Hofler, and Alan Schlottman, "Job Search and Immigrant Assimilation: An Earnings Frontier Approach, Review of Economics and Statistics 74:3, August 1992.

Dustmann, Christian, "Speaking Fluency, Writing Fluency and Earnings of Migrants," Journal of Population Economics 7:2, 1994.

Grenier, Gilles, "The Effect of Language Characteristics on the Wages of Hispanic American Males," Journal of Human Resources 19:1, Winter 1984.

Jasso, Guillermina and Mark Rosenzweig, "What's in a Name? Country-of-Origin Influences on the Earnings of Immigrants in the United States," in Research in Human Capital and Development 4, ed. Oded Stark, Greenwich, CT: JAI Press, 1986.

Katz, Lawrence and Kevin Murphy, "Changes in Relative Wages in the United States: Supply and Demand Factors," Quarterly Journal of Economics 107:1, February 1992.

Levy, Frank and Richard Murnane, "U.S. Earnings Levels and Earnings Inequality: A Review of Recent Trends and Proposed Explanations, "Journal of Economic Literature 30:3, September 1992.

Kossoudji, Sherrie, "English Language Ability and the Labor Market Opportunities of Hispanic and East Asian Immigrant Men," Journal of Labor Economics 6:2, April 1988.

McManus, Walter, "Labor Market Effects of Ethnic Enclaves," Journal of Human Resources 25:2, Spring 1990.

McManus, Walter, William Gould, and Finish Welch, "Earnings of Hispanic Men: The Role of English Language Proficiency," Joumal of Labor Economics 1:2, April 1983.

Rivera-Batiz, Francisco, "English Language Proficiency and the Economic Progress of 
Immigrants," Economic Letters 34, 1990.

-, "The Effects of Literacy on the Earnings of Hispanics in the United States." In Hispanics in the Labor Force, ed. Emilio Melendez, Clara Rodriguez, and Janis BarryFigueroa, New York: Plenum Publishers, 1991.

-, "English Language Proficiency and the Earnings of Young Immigrants in U.S. Labor Markets," Policy Studies Review 11, Summer 1992.

Tainer, Evelina, "English Language Proficiency and the Determination of Earnings among Foreign-Born Men," Journal of Human Resources 23:1, Wimer 1988. 
Table 1

Characteristics of Native and Imnigrant Workers, 1990

Fnaliah Speaking Ability

* Wage Education $\underset{\substack{\text { Inglish } \\ \text { Only }}}{\substack{\text { Very } \\ \text { Well }}}$ Well Not Well Not at all

Oaly Well

Natives

Europe

Mexico

Other $\boldsymbol{H}$.

Bemisphere

Africa and

Mid East

south Asia

Eart Asia.

Bnglish Speaking

All Immigrants
92.4

13.02

13.2

1.5

14.85

12.6

1.8

8.14

8.4

2.3

10.86

0.5

15.45

11.5

14.4

0.3

17.77

15.5

12.93

13.4

14.75

13.3

12.48

12.0

7.6

\begin{abstract}
12.48
\end{abstract}
95

35

4

9

19

12

13

90

25
34

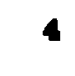

39

27

38

58

66

40

B
1

18

25

26

19

18

31

2

21

2

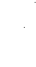

14

4

14

0

15

0

0

1

13

7

o

0

2

0

5

Note: Data are for full year workers age 18-64. 
Table 2

Nage Regreseions

Simple Cohort and Assimilation Bffect

Men

\begin{tabular}{lll}
\hline Al1 $\quad$ Bd 512 & Bd
\end{tabular}

Constant

Imm

YSM

YRM

$\mathbf{B \times p}$

Expgq/100

YR90

$\mathbf{R}^{2}$

NOBS $(000)$
1.894

(0.017)

1.869

$(.021)$

1.971

$(.026)$

$-.148$

$-.07 B$

$(.017)$

$(.021)$

$-.113$

.006

$(.001)$

.009

(.001)

.001

$(.002)$

$-.002$

$(.003)$

$-.008$

$(.000)$

$-.006$

(.001)

.059

(.000)

.049

$(.000)$

$-.106$

$(.000)$

$-.078$

(.001)

$-.093$

$(.001)$

$-.154$

(.002)

.13

1007
.16

514
(.026)

.011

(.001)

$-.015$

$(.003)$

$-.002$

(.001)

.065

$(.000)$

$-.112$

$(.001)$

$-.119$

(.002)

.17

493
Nomen

Fd 12

Bd 13

A11

1.743

1.065
$(.002)$

(.003)

1.935

$(.002)$

$-.100$

$(.020)$

-.135
$(.024)$

$-.074$

.012

(.001)

.010

(.031)

.028

(.003)

-.012
$(.003)$

$(.002)$

. .004

(.001)

$-.003$

(.001)

.002

.029

$(.000)$

.023

$(.000)$

.000

.059

$(.000)$

$-.037$

.082

.019

$(.001)$

$-.065$

(.002)

$-.014$

.04

704

.09

345 
Table 3

Years to Overtaking

Immigrante for Year of Arrival, Sex, and Education

Men

Women

year of

Arrival

\begin{tabular}{rrrrrrr} 
& Men & & \multicolumn{3}{c}{ Nomen } \\
\cline { 6 - 7 } Al1 & Eds12 & Edz12 & & All & Bds12 & Bdz12 \\
\cline { 6 - 7 } & & & & & \\
14.0 & 19.0 & 12.0 & & 9.9 & 16.4 & 6.5 \\
26.9 & 27.6 & 14.6 & 15.6 & 21.5 & 8.2 \\
40.6 & 36.6 & 17.5 & 24.2 & 28.0 & 10.1 \\
55.3 & 46.3 & 21.0 & 34.5 & 41.6 & 12.3
\end{tabular}

Note: Calculated from coefficients in Table 2. 


\begin{tabular}{lll}
\hline Al1 & Ed $\leq 12$ & Bd $\geq 12$
\end{tabular}

\begin{tabular}{|c|c|c|c|c|c|c|}
\hline Constant & $\begin{array}{l}1.420 \\
(.006)\end{array}$ & $\begin{array}{l}1.580 \\
(.007)\end{array}$ & $\begin{array}{l}-.780 \\
(.046)\end{array}$ & $\begin{array}{l}1.414 \\
(.008)\end{array}$ & $\begin{array}{l}1.631 \\
(.060)\end{array}$ & $\begin{array}{r}-1.054 \\
(.002)\end{array}$ \\
\hline YSM & $\begin{array}{c}.011 \\
(.001)\end{array}$ & $\begin{array}{l}.007 \\
(.001)\end{array}$ & $\begin{array}{l}.016 \\
(.001)\end{array}$ & $\begin{array}{l}.012 \\
(.001)\end{array}$ & $\begin{array}{l}.0085 \\
(.001)\end{array}$ & $\begin{array}{l}.016 \\
(.002)\end{array}$ \\
\hline YSMsq/100 & $\begin{array}{l}-.018 \\
(.002)\end{array}$ & $\begin{array}{l}-.008 \\
(.003)\end{array}$ & $\begin{array}{c}-.025 \\
(.003)\end{array}$ & $\begin{array}{l}-.0233 \\
(.0024)\end{array}$ & $\begin{array}{r}-.014 \\
(.003)\end{array}$ & $\begin{array}{l}-.030 \\
(.004)\end{array}$ \\
\hline $\mathrm{YRM} / 100$ & $-.117)$ & $\begin{array}{l}-.096 \\
(.060)\end{array}$ & $\begin{array}{l}-.044 \\
(.070)\end{array}$ & $\begin{array}{r}-.144 \\
(.05)\end{array}$ & $\begin{array}{l}-.03 \\
(.07)\end{array}$ & $\begin{array}{l}-.07 \\
(.08)\end{array}$ \\
\hline Exp & $\begin{array}{l}.054 \\
(.000)\end{array}$ & $\begin{array}{l}.049 \\
(.000)\end{array}$ & $\begin{array}{l}.059 \\
(.0003)\end{array}$ & $\begin{array}{l}.031 \\
(.000)\end{array}$ & $\begin{array}{l}.023 \\
(.000)\end{array}$ & $\begin{array}{l}.038 \\
(.000)\end{array}$ \\
\hline Expsq/100 & $\begin{array}{l}-.085 \\
(.000)\end{array}$ & $\begin{array}{l}-.074 \\
(.001)\end{array}$ & $\begin{array}{l}-.096 \\
(.001)\end{array}$ & $\begin{array}{l}-.050 \\
(.000)\end{array}$ & $\begin{array}{l}-.034 \\
(.001)\end{array}$ & $\begin{array}{l}-.069 \\
(.001)\end{array}$ \\
\hline IR90 & $\begin{array}{l}-.098 \\
(.001)\end{array}$ & $\begin{array}{l}-.166 \\
(.002)\end{array}$ & $\begin{array}{c}-.034 \\
(.002)\end{array}$ & $\begin{array}{c}-.007 \\
(.001)\end{array}$ & $\begin{array}{l}-.074 \\
(.002)\end{array}$ & $\begin{array}{l}.050 \\
(.002)\end{array}$ \\
\hline Ed & $\begin{array}{l}-.001 \\
(.001)\end{array}$ & $\begin{array}{l}-.030 \\
(.002)\end{array}$ & $\begin{array}{l}.272 \\
(.006)\end{array}$ & $\begin{array}{l}-.039 \\
(.001)\end{array}$ & $\begin{array}{l}-.071 \\
(.002)\end{array}$ & $\begin{array}{l}.283 \\
(.008)\end{array}$ \\
\hline Edsq/100 & $\begin{array}{l}.348 \\
(.003)\end{array}$ & $\begin{array}{l}.472 \\
(.010)\end{array}$ & $\begin{array}{c}-.539 \\
(.018)\end{array}$ & $\begin{array}{l}.519 \\
(.004)\end{array}$ & $\begin{array}{c}.685 \\
(.013)\end{array}$ & $\begin{array}{l}-.552 \\
(: 025)\end{array}$ \\
\hline Very well & $\begin{array}{l}-.047 \\
(.003)\end{array}$ & $\begin{array}{l}-.034 \\
(.004)\end{array}$ & $\begin{array}{c}-.054 \\
(.004)\end{array}$ & $\begin{array}{l}.022 \\
(.003)\end{array}$ & $(.014)$ & $\begin{array}{l}.014 \\
(.004)\end{array}$ \\
\hline Nell & $\begin{array}{l}-.081 \\
(.004)\end{array}$ & $\begin{array}{l}-.051 \\
(.005)\end{array}$ & $\begin{array}{c}-.147 \\
(.007)\end{array}$ & $\begin{array}{c}-.025 \\
(.005)\end{array}$ & $\begin{array}{l}.002 \\
(.006)\end{array}$ & $\begin{array}{l}-.071 \\
(.008)\end{array}$ \\
\hline Not well & $\begin{array}{l}-.138 \\
(.006)\end{array}$ & $\begin{array}{l}-.127 \\
(.007)\end{array}$ & $\begin{array}{r}-.215 \\
(.011)\end{array}$ & $\begin{array}{l}-.065 \\
(.006)\end{array}$ & $\begin{array}{l}-.053 \\
(.008)\end{array}$ & $\begin{array}{l}-.149 \\
(.012)\end{array}$ \\
\hline No English & $\begin{array}{l}-.210 \\
(.010)\end{array}$ & $\begin{array}{l}-.225 \\
(.010)\end{array}$ & $\begin{array}{l}-.385 \\
(.036)\end{array}$ & $\begin{array}{l}-.090 \\
(.011)\end{array}$ & $\begin{array}{l}-.128 \\
(.012)\end{array}$ & $\begin{array}{l}-.261 \\
(.041)\end{array}$ \\
\hline Europe & $\begin{array}{l}-.000 \\
(.016)\end{array}$ & $\begin{array}{l}.097 \\
(.021)\end{array}$ & $\begin{array}{l}-.151 \\
(.025)\end{array}$ & $\begin{array}{l}-.056 \\
(.019)\end{array}$ & $\begin{array}{l}-.005 \\
(.025)\end{array}$ & $\begin{array}{l}-.166 \\
(.029)\end{array}$ \\
\hline Mexico & $\begin{array}{c}-.092 \\
(.017)\end{array}$ & $\begin{array}{l}-.048 \\
(.022)\end{array}$ & $\begin{array}{l}-.260 \\
(.028)\end{array}$ & $\begin{array}{l}-.114 \\
(.020)\end{array}$ & $\begin{array}{l}-.087 \\
(.026)\end{array}$ & $\begin{array}{l}-.247 \\
(.033)\end{array}$ \\
\hline Other w. Hemis & $\begin{array}{l}-.154 \\
(.017)\end{array}$ & $\begin{array}{l}-.111 \\
(.023)\end{array}$ & $\begin{array}{l}-.223 \\
(.026)\end{array}$ & $\begin{array}{l}-.117 \\
(.020)\end{array}$ & $\begin{array}{c}-.081 \\
(.026)\end{array}$ & $\begin{array}{l}-.196 \\
(.030)\end{array}$ \\
\hline $\begin{array}{l}\text { Africa and } \\
\text { Mid East }\end{array}$ & $\begin{array}{l}-.099 \\
(.018)\end{array}$ & $\begin{array}{l}.002 \\
(.026)\end{array}$ & $\begin{array}{l}-.197 \\
(.027)\end{array}$ & $\begin{array}{l}-.053 \\
(.023)\end{array}$ & $\begin{array}{l}.027 \\
(.032)\end{array}$ & $\begin{array}{l}-.252 \\
(.033)\end{array}$ \\
\hline s. Asia & $\begin{array}{l}-.097 \\
(.019)\end{array}$ & $\begin{array}{l}-.132 \\
(.034)\end{array}$ & $\begin{array}{l}-.144 \\
(.027)\end{array}$ & $\begin{array}{l}-.116 \\
(.024)\end{array}$ & $\begin{array}{l}.024 \\
(.038)\end{array}$ & $\begin{array}{l}-.199 \\
(.033)\end{array}$ \\
\hline E. Asia & $\begin{array}{l}-.142 \\
(.017)\end{array}$ & $\begin{array}{l}-.149 \\
(.023)\end{array}$ & $\begin{array}{l}-.187 \\
(.026)\end{array}$ & $\begin{array}{l}-.071 \\
(.019)\end{array}$ & $\begin{array}{c}-.082 \\
(.026)\end{array}$ & $\begin{array}{l}-.119 \\
(.030)\end{array}$ \\
\hline English speaixing & $\begin{array}{l}-.040 \\
(.017)\end{array}$ & $\begin{array}{l}.003 \\
(.022)\end{array}$ & $\begin{array}{l}-.123 \\
(.025)\end{array}$ & $\begin{array}{l}-.006 \\
(.019)\end{array}$ & $\begin{array}{l}.016 \\
(.025)\end{array}$ & $\begin{array}{l}-.073 \\
(.029)\end{array}$ \\
\hline$R^{2}$ & .27 & .19 & .27 & .20 & .07 & .20 \\
\hline NOBS $(000)$ & 1007 & 514 & 493 & 704 & 360 & 345 \\
\hline
\end{tabular}


Ianguage Regreasions for Immigrants

Cohort and Aasimilation Bffects

\section{Constant}

YRM

YSM

YSMøq/100

Agem

Agemsq/100

$\mathbf{R}^{2}$

NOBS
16.649

(1.009)

$-.007$

(.001)

.037

(.001)

$-.040$

$(.000)$

$-.046$

(.001)

.038

$(.001)$

.20

187,936 
Table 6

Region of Origin by Decade of Arrival

Innigrants, 1990

\section{0}

Burope

Mexico

Other Western

Hemi ephere

\section{Africa and Middle East}

\section{S. Asia \\ E. Agia}

English Speaking

Average

Education

10.4

B. 4

3.2

0.4

10.5

19.7

12.9

47.45

26.64

2.1

13.3

17.7

22.6

3.6

6.5

4.3

24.9

11.8

11.8

4.8

24.6

10.5

13.8

0.4t

23.4

22.7

5. 8

5.2

.5

20.4

12.0 
Table 7

Average Bducation, Imnigrants 1990

by Region of Origin and Age at Migration

Age at Migration

$\begin{array}{rrrr}0-10 & 21-20 & 26+\end{array}$

\begin{abstract}
Burope
Mexico

Other Western

Bemisphere
\end{abstract}

Africa and

Middle Bast
S. Asia
E. Asia
Bnglish speaking

13.5

11.3

23.5

14.3

14.8

13.7

13.6
12.2

8. 3

11.8

14.3

14.7

13.3

13.2

12.0

12.2

7.9

6.7

11.4

10.6

14.6

14.3

16.0

15.5

13.8

13.1

13.4

13.1 
Table 8

Cohort Bffects

English Skills

Education

Region of Birth

Residual

English Skills

Residual
Men

Ed $\leq 12$

Ed $>12$

0.3

3.6

95.0

1.1

1.2

12.6

87.2

$-1.0$

0.6

Bd $\leq 12$

Bd > 12

0.2

0.8

22.7

73.1

3.4

\section{Assimilation Effecto}

16.4

83.6
18.0

82.0
5.9

94.1
9.9

90.1 